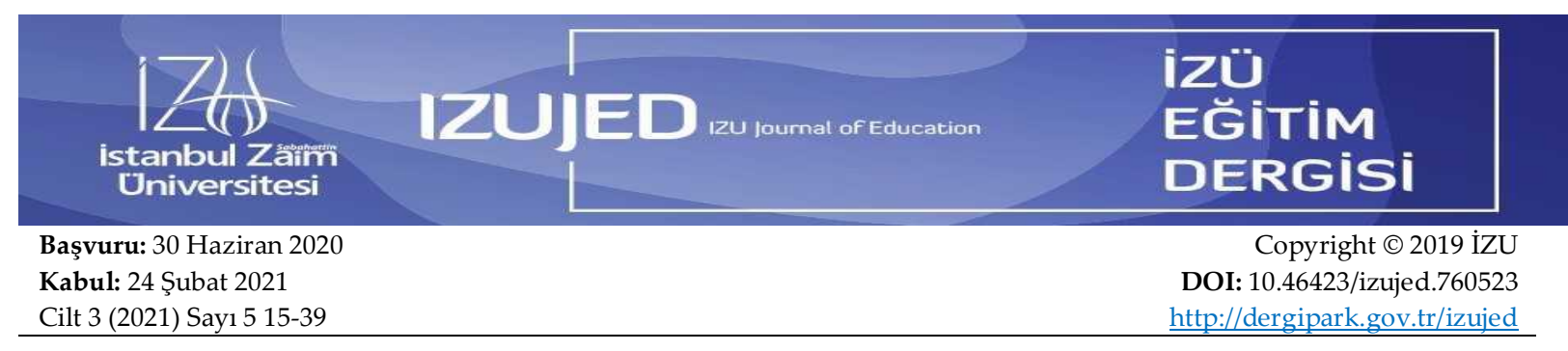

\title{
Yönetim Süreçleri Bağlamında Bilgievlerinin İncelenmesi: Küçükçekmece Belediyesi Örneği
}

\author{
Erdi DEMIRa
}

Esra TÖREb

\begin{abstract}
Öz
Bu araştırmanın amacı bilgievlerinin yönetim süreçlerinin incelenmesidir. Araştırmanın çalışma grubu, Küçükçekmece Belediyesine bağlı 10 bilgievinde çalışan bir koordinatör, beş yönetici ve beş öğretmenden oluşmaktadır. Çalışma grubuyla yapılan görüşmelerde karar verme, planlama, iletişim, örgütleme, etkileme, koordinasyon ve değerlendirme gibi yönetim süreçlerine dair özellikler incelenmiştir. Araştırmada veri toplama aracı olarak "Nitel Araştırma" yöntemi tercih edilmiştir. "Olgubilim/Fenomoloji" deseni kullanılmış ve "Yarı Yapılandırılmış Görüşme" tekniğinden faydalanılmıştır. Araştırmada, katılımcılara 12 adet soru yöneltilmiş ve sorulara verilen yanıtlar analiz edilmiştir. Araştırmada elde edilen bulgular incelendiğinde, bilgievlerinde yönetim süreçleri açısından etkili olan en baskın unsurların "Kişi Odaklı" unsurlar olduğu sonucuna varılmıştır. Yöneticilerin kişisel özelliklerinin ve yeterliliklerinin, yönetim süreçlerinin önemli bir kısmında etkin bir şekilde varlığını gösterdiği bulgusuna ulaşılmıştır. Araştırma bulgularından yola çıkılarak uygulayıcılara ve araştırmacılara önerilerde bulunulmuştur.
\end{abstract}

Anahtar Sözcükler: Eğitim yönetimi, yönetim süreçleri, yerel eğitim, bilgievi

\section{Examination of Bilgievi in the Context of Management Processes: Sample of Kucukcekmece Municipality}

\begin{abstract}
The aim of this study is to examine the management processes of information systems. The working group of the study consists of 1 coordinator, 5 administrators and 5 teachers working in 10 Bilgievi of Küçükçekmece Municipality. During the interviews with the working group, the characteristics of management processes such as decision-making, planning, communication, organizing, influencing, coordination and evaluation were examined. In the research, "Qualitative Research" method was preferred as data collection tool. Phenomology pattern was used and "Semi-Structured Interview" technique was used. In the study, 12 questions were asked to the participants and their answers were analyzed. When the findings obtained in the study are examined, it is concluded that the most dominant elements in the information systems in terms of management processes are "Person-Oriented" elements. It has been found that the personal characteristics and competencies of the managers effectively show their presence in a significant part of the management processes. Based on the research findings, suggestions were made to the practitioners and researchers.
\end{abstract}

Key Words: Education management, management processes, local education, bilgievi

a Küçükçekmece Belediyesi Bilgievleri, İstanbul, Türkiye E-mail: erdidemirim@gmail.com ORCID: 0000-0003-2824-4421

*Bu çalışma, Erdi Demir'in, Dr. Öğretim Üyesi Esra TÖRE danışmanlığında İstanbul Sabahattin Zaim Üniversitesi Sosyal Bilimler Enstitüsünde yaptığı lisansüstü tezin bir bölümünden üretilmiştir.

\footnotetext{
b Sorumlu Yazar: Dr. Öğretim Üyesi Esra TÖRE. İstanbul Sabahattin Zaim Üniversitesi, Eğitim Fakültesi, İstanbul, Turkey, E-mail: esra.tore@izu.edu.tr ORCID: 0000-0001-9133-6578

Atıf: Demir, E. ve Töre, E. (2021). Yönetim Süreçleri Bağlamında Bilgievlerinin İncelenmesi:

Küçükçekmece Belediyesi Örneği İZ̈̈ Eğitim

Dergisi, 3 (5) 15-39 DOI: 10.46423/izujed.760523
} 


\section{Extended Abstract}

\section{Introduction}

Turkish Prime Minister Recep Tayyip Erdoğan first used the Bilgievi (knowledgehouse) term in 2004. Erdoğan spoke for the first time about the Bilgievi model in order to protect children and young people from the dangers of the streets and to ensure that their out-of-school time is spent with useful activities. In 2005, Zeytinburnu Municipality opened its first information in these periods when the information was not clearly defined in terms of legal and theoretical aspects. In the following years, various municipalities have put their Bilgievi projects into service (Kavi and Koçak, 2010: 568-569).

The Bilgievi, since its establishment in 2004 to 2019, continues to grow together in the last 14year period and has continued to spread throughout Turkey. However, it is seen that the development of the concept of Bilgievi in the theoretical and academic field is rather weak compared to the willingness of municipalities to establish and operate information. While there are many studies related to municipalism in the literature, there are limited studies on the services provided by municipalities based on children and youth (Yavuz, 2013: 1).

Research on the Bilgievi, which have turned into a service tool of municipalities, is very new and extremely limited. For making a common definition of Bilgievi, drawing legal boundaries and starting from the physical structure, it is thought that a systematic road map should be drawn on issues such as education model, assessment and evaluation, personnel qualifications and employment. Based on these reasons, in this study, it is aimed to examine the characteristics of information systems in the context of management processes.

\section{Method}

The research was carried out with the phenomenological design of qualitative research methods. Maximum diversity sampling was used. The study group of the research was actively working in the Bilgievi between 2018-2019; coordinator, bilgievi manager and bilgievi teachers. The number of personnel contributing to the research is 11 ; as 1 coordinator, 5 administrators and 5 teachers. In order to represent the study population, the participants; gender, age, seniority and the position chosen in a balanced way to create diversity in the study.In order to reach systematic and in-depth information, semi-structured interview form, which was formed by taking the expert opinion by the researchers, was preferred (Miles and Huberman, 2015: 34; Yıldırım \& Şimşek, 2013: 150-151). The validity and reliability of the questionnaire were tried to be increased by asking repetitive questions, making detailed quotations, detailed analysis, detailed description and receiving participant confirmation (feedback / feedback) strategies. The semi-structured interview forms were applied to the information staff by the researcher on predetermined dates and environments and the interviews were recorded with the consent of the participants. A total of 189 minutes of audio recordings were recorded and analyzed in the order of the participants.Content analysis was used for data analysis. 


\section{Findings and Discussion}

Findings and discussion related to the research questions are presented respectively. Information paths in the decision-making process in bilgievi are grouped in person-oriented, institution-oriented and institutional framework themes in order of frequency. Özkalp (1991: 318) found that executives consulted personnel in some decisions while taking certain decisions within the scope of their institutional powers, and in part, they left some decisions directly to personnel. In some group decisions, it is also possible that individuals do not behave independently.

Considering the factors that are effective in decision making, the themes of "political structure" and "neighborhood needs" come to the forefront. Gokce, Sahin and Orselli (2002) 's research Political power, in the election and appointment of managers rather than criteria such as merit and experience; reliability, secrecy and keeping the party's interests ahead of everything. In the municipalities, which are a bureaucratic and political system, it is possible that many processes, especially the decision-making process, will be affected by politics. There are concrete realities such as the formation of power coalitions and the efforts of individuals and groups to influence each other. For this reason, political behaviors; It can be exhibited by managers, teachers and other stakeholders. This is a natural example of a person's tendency to act strategically and in line with his own interests (Altun and Sarpkaya, 2017: 10).

When the communication tools used in the bilgievi are examined, it is seen that internet based applications and mutual communication themes come to the forefront. Uzun and Uluçay (2017: 228) stated that the tools that contain media richness increase the effectiveness of communication. When the problems encountered in the communication process are examined, two themes come to the fore, namely problems arising from individuals and tools. The question of whether people were placed in accordance with the nature of the work during the organization process was answered by most of the participants. Skills and close relationships are effective in the organization process.It has been found that there are two basic criteria as personal information and professional characteristics for sharing task in the Bilgievi. In the theme of personal traits, there are sub-themes such as abilities, volunteering, psychological status and personal relationships; there are sub-themes of branches, trainings and commissions on the subject of professional characteristics.

It found that managers use abstract and concrete tools in the process of influencing employees. In the Bilgievi, the coordination between jobs and people is grouped under the themes of group-oriented, person-oriented and institution-oriented. In the Bilgievi, it is checked whether or not corporate goals are achieved by means of "feedback" and "tools. In the Bilgievi, managers evaluate the processes related to education and personnel through student - parent satisfaction, observations, one - to - one interviews, meetings and reports. Topuz and Yilmaz (2019: 103) found that teachers' knowing that they would be subject to an evaluation and evaluating them according to certain criteria required teachers to be in constant preparation.

Based on the results of the research, it is recommended that the practitioners follow a pluralistic method in the decision-making process, consult with the meeting during the planning process, establish face-to-face communication, conduct communication within the institution through registered correspondence, and include merit and skill centered decisions in the organization process. Researchers are advised to conduct studies on the dimensions or integration of cooperation with the Ministry of National Education. 


\section{Giriş}

21. yüzyıl yaşantısının içerisine bilgi ve iletişimin dâhil edilmediği bir yorumlama, içerisinde eksiklikler barındıracaktır. 21. yüzyıl tüm yönleriyle bilgi ve enformasyon üzerine kuruludur. Bu yüzyılda yaşayan insanların yüksek erişimli bilgiyle tanışması, özellikle bu yüzyılın ilk çeyreğinde yaşam standartlarında devrim niteliğinde değişimler yaratmıştır. Bilgi ve iletişim alanındaki hızlı gelişim; toplumu, sanayi toplumundan bilgi toplumuna dönüştürmüştür. $\mathrm{Bu}$ dönüşümün temel noktalarından biri de bilgisayarlar ve bilgisayar teknolojisinde yaşanan hızlı değişimlerdir (Kırık, 2007: 1).

90'lı yıllardan bugüne toplumun önemli bir kesiminin ilgisini çeken, gittikçe hızı artan, yaygınlaşan ve yapısı değişen internet, ülkemizde toplum yapısının değişmesinde önemli bir rol oynamıştır. (Kuzu, 2011: 10). Bu değişimler olumluluklar barındırdığı gibi olumsuzluklar da barındırmaktadır. Ebeveyn denetimine ihtiyaç duyan çocukların, bu hızlı ve ulaşılabilir erişim kaynaklarına denetimsiz ortamlarda müracaat edebilmesi, psikososyal gelişimleri üzerinde kontrolsüz bir etki meydana getirmeye başlamıştır. Araştırmalar interneti yaygın bir biçimde kullanan ve zamanını bilgisayar oyunları oynayarak geçiren çocukların sosyal gelişimleri önemli ölçüde gerilediğini göstermektedir. Bu çocukların öz güvenleri düşük, sosyal kaygı düzeylerinin ve saldırganlık davranışlarının yüksek olduğu görülmektedir (Cömert ve Kayıran, 2010: 167). Bireylerin yaşları arttıkça ve internetin iletişim amaçlı kullanımının sağladığı faydalar arttıkça internet kafelere ilişkin olumlu görüşlerin azaldığı, bireylerin interneti kullanma süreleri ve psikososyal sorunları arttıkça internet kafelere dair görüşlerin olumlu yönde arttığ1 tespit edilmiştir (Kuzu, 2011: 26).

Bilgievlerinin yaygınlaşmaya başladığı 2006 yılında RTÜK tarafından yapılan araştırmaya göre ilköğretim öğrencilerinin \%52.8'inin evlerinde bilgisayar bulunmadığ $1, \% 47.2$ 'sinin ise evinde bilgisayar bulunduğu tespit edilmiştir. Bilgisayara sahip olan öğrencilerin \%51.5'inin internet bağlantısının olmadığı ortaya 21 çıkmıştır. Dolayısıyla internete ve bilgisayara kolayca erişim sağlayamayan çocuklar, internet kafelere yönlenmeye başlamıştır. İnternet kafelerdeki kontrolsüz ve yanlış yönlendirmelere müsait ortam, çocuklar için bir tehdit konumuna gelmiştir. Bilgievlerinin kuruluşu ise çocukların yaygın bir biçimde internet kafelere başvurması, boş zamanlarının birçoğunun sokaklarda geçirmesi ve buradan gelebilecek tehlikelerle yakından ilgilidir (Kırık, 2007: 5).

"Bilgievi" kavramı ilk defa 2004 yılında dönemin Başbakanı Recep Tayyip Erdoğan tarafından kullanılmıştır. Erdoğan, çocukları ve gençleri sokakların tehlikelerinden korumak ve okul dışı zamanları, faydalı etkinliklerle geçirilmesini sağlamak adına ilk defa bilgievi modelinden söz etmiştir. Bilgievlerinin yasal ve kuramsal yönden henüz net bir şekilde tanımlanmadığı bu dönemlerde ilk bilgievini 2005 yılında Zeytinburnu Belediyesi açmıştır. İzleyen yıllarda çeşitli belediyeler bilgievi projelerini hizmete sokmuşlardır (Kavi ve Koçak, 2010: 568-569).

"Bilgievi" kavramı, "bilgi" ve "ev" sözcüğünün birleşimi sonucu ortaya çıkmış ve bu birleşimle bir eğitim terimi haline gelmiştir. Bilgi merkezli kurumlar olması sebebiyle ve geçmişten gelen ilhamla bu yapıların ismi "bilgi"nin olduğu ortam, yani "Bilgievi” olarak nitelendirilmiştir. "Ev" sözcügüüün birincil anlamı, TDK (2011) sözlüğünde: "Bir kimsenin veya ailenin içinde yaşadığı yer, konut, hane" olarak ifade edilmiştir ancak "ev" sözcügünün birincil anlamının dışında kullanıldığı isimlendirmeler de mevcuttur. Bunlara“gözlemevi, dikimevi, huzurevi, cezaevi, kitabevi, konukevi ve cemevi" örnek olarak verilebilir (TDK, 2011: 834). Bu örneklerde olduğu gibi "ev" sözcüğü, çeşitli tamlamalarla birlikte terimleşmiş, 
ilk çıkış noktasından uzaklaşmıştır. Ortaya çıkan yeni tamlamalar, farklı anlamları temsil etmiştir. Bilgievleri ise bunun aksine yaygın bir biçimde, belediyeler tarafından "Bilgi evi" olarak kabul görmüştür. Bu yeni bilgi ortamları; huzurevi, dikimevi yahut konukevi gibi yeni bir yapıyı temsil ediyorsa, doğru kullanımı "bilgievi" olmalıdır. Bu kullanımın, hem kurumsallaşma açısından hem de yeni bir yapıyı temsil ettiğini göstermesi bakımından etkili olduğu düşünülmektedir.

Bilgievleri, kurulduğu 2004 yılından 2019 yılına kadar aradan geçen 14 yıllık süreçte büyümesini sürdürmekte ve Türkiye genelinde yaygınlaşmaya devam etmiştir. Ancak belediyelerin, bilgievi kurmak ve işletmekteki istekliliklerine nazaran "Bilgievi" kavramının teorik ve akademik sahadaki gelişimi ise oldukça zayıf olduğu görülmektedir. Alanyazında belediyecilik ile ilgili birçok çalışma mevcutken belediyelerin çocuk ve gençlik temelinde verdiği hizmetleri elealan çalışmalar ise son derece sınırlıdır (Yavuz, 2013: 1).

Yavuz (2013)'un yaptığı araştırmaya göre 2013 yılı itibariyle Türkiye genelinde 229 bilgievi mevcuttur. Araştırmanın devamında bilgievlerinin büyük çoğunluğunun (138) İstanbul'da hizmet verdiği ifade edilmiştir. Diğer bilgievleri ise 28 şehre yayılmakta ve varlığını sürdürmektedir (Yavuz, 2013:52). Araştırmanın yapıldığı 2013 yılından 2019 yılına kadar geçen altı yıllık süre boyunca bilgievi sayısının arttığı düşünülmektedir. İnternet arama motorları kullanılarak yapılan ayrıntılı taramalar ve faaliyet raporlarına göre 2019 itibariyle Türkiye genelinde 246 bilgievi olduğu verisine ulaşılmıştır. Bu veri, bilgievi sayısının arttığını ortaya koymaktadır. Türkiye geneline yayılan bilgievleri, 160 birimle en çok İstanbul'da bulunmaktadır. İstanbul'dan sonra en fazla bilgievi bulunan iller ise Kocaeli ve Ankara'dır.

Tarihteki bilgievlerine benzer kurumlara bakıldığında, Osmanlı döneminde bugünkü bilgievlerine yakın eğitim hizmetleri camiler, medreseler, mektepler ve loncalar olduğu görülemektedir. Bu kurumlar arasında Osmanlı toplumunda, ilkokul seviyesinde eğitim hizmeti veren kurumlar genellikle sibyan mektepleridir. Burada verilen eğitimler, din ve ahlak temelli bir yapı izlemektedir (Doğan, 1997: 415). Sibyan mekteplerinin yönetimiyle ilgilenen kişiler ise Müftüler ve Şeyhülislamlar olmuştur. Bu tarz mekteplerin belirli bir yönetmeliği, devletçe yahut herhangi bir kurum tarafından düzenlenmiş öğretim programları bulunmamaktaydı. Bu merkezlerde din ve ahlak temelli eğitimler, ilkokul düzeyinde verilmekte ve ayrıca bu kurumlar merkezi bir eğitim sisteminden bağımsız yerel olanaklara göre işlev görmekteydi (Doğan, 1997: 414). Eğitim içeriği yönüyle olmasa da yerel ihtiyaçlara karşılık verebilmesi açısından bilgievleri ile Osmanlının bazı eğitim kurumları arasında çeşitli benzerlikler olduğu düşünülmektedir. Bilgievlerinin tarihselliğinin anlaşılması açısından, organik bağlantısı zayıf olmasına rağmen "Köy Enstitüleri" önemli bir örnektir. Köy Enstitülerinin eğitim programlarının maksadı: Köyde yaşayan çocukların eğitimiyle; aile, köy ve köy halkının birçok açıdan geliştirilmesidir (Yılmaz, 2013: 75). Bilgievleriyle ilintili noktalardan birisi de aralarındaki amaçsal benzerliktir.

Köy enstitülerinde, bireylerin gelişimleri için önemli olan "Okuma-Yazma” geliştirme eğitimleri, günün belirli periyotlarında yapılan "Özgür Okuma” programları; kişinin sosyal, kültürel ve sanatsal yönünü geliştirmek için tasarlanan etkinlikler ve 1953 programında öne çıkan "Çocuk Edebiyatı" dersi, Köy Enstitülerinin, bilgievlerinin eğitsel amaçlarıyla yakınlık gösterdiğini ortaya koymaktadır (Demircan, 2007: 21). Ancak ne Osmanlı döneminin bilgi kurumları ne de Cumhuriyet döneminin bilgi kurumları, tam anlamıla bugünkü bilgievlerinin çıkış noktası kabul edilebilir. Bilgievleri sabit bir tarihsel uzantıdan bağımsız 
müstakil ve biricik özelliklerde yapıda olduğu; Türk Milli Eğitim sisteminde kendine has bir yapıyı ve işlevi temsil ettiği düşünülmektedir.

Belediyelerin bir hizmet aracına dönüşmüş olan bilgievlerine dair araştırmalar, çok yeni ve sayıca son derece sınırlıdır. Çavuş ve arkadaşları (2013), "İnformal Öğrenme Ortamlarının Çevre Bilinci Kazandırmasına İlişkin Öğretmen Görüşleri: Kocaeli Bilgievleri Örneği" adlı makaleleri ile bilgievleri konusundaki ilk çalışmayı alanyazınına kazandırmışlardır. Yine aynı yıl Yavuz (2013), sonraki yıllarda Karadeniz (2017) Bilgievleri konusunda çalımışlardır. Bilgievlerinin yasal dayanakları olan "5393 Sayılı Belediye Kanunu", "Kamu Kurum ve Kuruluşları, Belediyeler, Vakıflar, Dernekler ve Meslek Odaları Tarafından Millî Eğitim Bakanlığının Denetim ve Gözetiminde Ücretsiz Olarak Açılacak Yaygın Eğitim Amaçlı Kurslar Yönergesi" ve "Millî Eğitim Bakanlığı Yaygın Eğitim Kurumları Yönetmeliği” esas alındığında bilgievlerinin kurulması ve işleyişi sürecinde bir yöntem belirtilmediği görülmektedir. Bilgievlerinin ortak bir tanımının yapılması, yasal olarak sınırlarının çizilmesi ve fiziki yapıdan başlayarak; eğitim modeli, ölçme değerlendirme, personel nitelikleri ve istihdam gibi konularda sistemli bir yol haritası çizilmesi gerektiği düşünülmektedir. Bu gerekçelerden yola çıkılarak bu çalışmada yönetim süreçleri bağlamında bilgievlerinin özelliklerini incelemesi amaçlanmıştır.

\section{Yöntem}

\section{Araştırmanın Modeli}

$\mathrm{Bu}$ araştırmada, araştırma konusunun doğasına uygun olarak Olgubilim/Fenomenoloji deseni kullanılmıştır. Olgubilim deseni, farkında olduğumuz ancak derinlemesine ve ayrıntılı bir anlayışa sahip olmadığımız olgulara odaklanmaktır. Olgular; yaşadığımız ünyada olaylar, deneyimler, algılar, yönelimler, kavramlar ve durumlar gibi çeşitli biçimlerde karşımıza çıkabilmektedir. Olgularla günlük yaşantıda sık sık karşılaşılsa da bu tanışıklık onların tam olarak anlaşıldığı anlamına gelmez. İnsanlara tümüyle yabancı olmayan aynı zamanda da tam anlamının kavranamadığı olguları araştırmayı amaçlayan çalışmalar için, Olgubilim iyi bir araştırma zemini oluşturmaktadır (Yıldırım ve Şimşek, 2013: 78; Ersoy, 2016: 53; Büyüköztürk vd. 2012:20).

\section{Çalışma Grubu}

Araştırmada, amaçlı örnekleme yöntemlerinden maksimum çeşitlilik örneklemesi kullanılmıştır. Amaçlı örnekleme zengin bilgiye sahip olduğu düşünülen durumların derinlemesine çalışılmasına olanak sağlar, olgu ve olayların keşfedilmesinde ve yorumlamasında yararlı olur (Yıldırım ve Şimşek, 2013: 135). Maksimum çeşitliliğe dayalı bir örneklem oluşturmada amaç, ortaya konulmak istenen problem, süreç ve olayla ilgili farklı bakış açlarını yansıtan durumların seçilmesinin istenmesidir (Creswell, 2013: 292). Bu sayede araştırma ile ilgili tarafların (yönetici ve öğretmen) niteliklerinde gözlenen çeşitlilik en yüksek düzeyde yansıtılabilmiştir. Katılımcıların belirlenmesinde gönüllülük esasına uygun hareket edilmiş ve her bir katılımcıya isimlerinin çalışmanın hiçbir evresinde kullanılmayacağı belirtilmiştir. Katılımcılar kod isimler verilmiştir.

Türkiye'de 2013 yılı esas alındığında, 29 şehirde toplam 229 adet bilgievi bulunmakta ve bunlardan 138'i İstanbul'da bulunmaktadır. (Yavuz, 2013: 52) İstanbul'da bulunan bilgievlerinden Küçükçekmece ilçesine bağlı olarak hizmet veren 10 bilgievi mevcuttur. 
Küçükçekmece Belediyesi, Gençlik ve Spor Hizmetleri Müdürlüğüne bağlı olarak hizmet veren 10 bilgievinde 125 personel mevcuttur. Personeller içerisinde: Koordinatör, yönetici, öğretmen ve yardımcı destek hizmetliler mevcuttur. Araştırmanın çalışma grubunu ise 20182019 yılları arasında bilgievlerinde aktif olarak çalışan; koordinatör, bilgievi yöneticisi ve bilgievi öğretmenleri oluşturmaktadır. Araştırma, 31 Mart 2019 yerel seçimleri öncesindeki faaliyetleri ve personel kadrosunu esas almaktadır. Araştırmaya katkı sunan personellerin sayısı ise 11 'dir.

11 katılımcı arasında; 1 koordinatör, 5 yönetici ve 5 öğretmen yer almaktadır. Çalışma evrenini temsil edebilmesi açısından katılımcılar; cinsiyet, yaş, kıdem ve çalışılan pozisyon bakımından dengeli bir şekilde seçilerek araştırmada çeşitlilik oluşturması amaçlanmıştır. Katılımcılara ilişkin bilgiler Tablo 1'de verilmiştir.

Tablo 1. Katılımcılara İlişkin Demografik Bilgiler

\begin{tabular}{ccccc}
\hline Kod & İş Tanımı & Cinsiyet & Yaş & Kıdem \\
\hline K1 & Koordinatör & Erkek & 46 & 5 \\
& & & & 11 \\
\hline K2 & Yönetici & Erkek & 47 & 11 \\
\hline K3 & Yönetici & Kadın & 42 & 8 \\
\hline K4 & Yönetici & Erkek & 39 & 11 \\
\hline K5 & Yönetici & Erkek & 40 & 4 \\
\hline K6 & Yönetici & Kadın & 40 & 6 \\
\hline K7 & Öğretmen & Erkek & 29 & 3 \\
\hline K8 & Öğretmen & Kadın & 28 & 4 \\
\hline K9 & Öğretmen & Erkek & 38 & 6 \\
\hline K10 & Öğretmen & Kadın & 27 & 4 \\
\hline K11 & Öğretmen & Kadın & 30 & \\
\hline
\end{tabular}

Tablo 1'de görüldüğü üzere, 1 koordinatör, 5 yönetici ve 5 öğretmenden oluşan 11 katılımcının “cinsiyet" değişkenine göre 6'sı (\%54,6) "erkek", 5'i (\%45,5) "kadın”dır. Aynı katılımcı grubu, "yaş" değişkenine göre; “21-30" yaş aralığında 4 kişi $(\% 36,4)$ "31-40” yaş aralığında 4 kişi $(\% 36,4)$ ve "41-50" yaş aralığında $3(\% 27,2)$ kişiden oluşmaktadır. "Kıdem" değişkenine göre ise "1-5 yıl" aralığında tecrübesi olanların sayısı 5 (\%45,5) ve "6-11 yıl" aralığında tecrübeye sahip katılımcıların sayısı 6'dır (\%54,5).

\section{Veri Toplama Araçları}

Araştırmada sistematik ve derinlemesine bilgiye ulaşmak amacıyla, araştırmacılar tarafından uzman görüşü alınarak oluşturulan yarı yapılandırılmış görüşme formu tercih edilmiştir (Miles ve Huberman, 2015: 34; Yıldırım ve Şimşek, 2013: 150-151). Yarı yapılandırılmış görüşmede araştırmacı, görüşme sorularını önceden hazırlar, kişilere sınırlı (kısmi) bir esneklik sağlayarak soruları yeniden düzenleyebilir. (Yıldırım ve Şimşek, 2005; Kılınç, 2007; Karasar, 2009). Görüşme formu ilgili alanyazın incelenerek hazırlanmış, ikisi eğitim yönetimi alanında biri ise sağlık alanında çalışan 3 uzmanın görüşüne başvurularak olumlu görüş alınmış, amaca göre hazırlanan sorular alanda çalışmaya devam eden 3 öğretmene yöneltilerek soruların anlaşılırlığı test edilmiştir. Bu esnada sorular amaca uygunluk, 
anlaşılırlık ve işlerlik boyutları ile değerlendirilmiştir. Soru formunun geçerlilik ve güvenirliği tekrarlı sorular sorma, ayrıntılı alıntılar yapma, ayrıntılı analiz, ayrıntılı betimleme ve katılımcı teyidi (geribildirim/dönüt) alma stratejileri ile arttırılmaya çalışılmıştır.

\section{Verilerin Toplanması}

Planlanan görüşmeler, uygulamaya koyulmadan önce Küçükçekmece Belediyesi Gençlik ve Spor Hizmetleri Müdürlüğ̈̈'nden gerekli izinler alınmış ve çalışma grubuyla paylaşılmıştır. Veri toplama araçlarından yarı yapılandırılmış görüşme formları, bilgievi personellerine önceden belirlenen tarih ve ortamlarda araştırmacı tarafından uygulanmış ve görüşmeler katılımcıların da onayıyla ses kaydına alınmıştır. Alınan toplam 189 dakika ses kaydı katılımcı sırasına göre yazıya çekilmiş ve analiz edilmiştir.

\section{Verilerin Analizi}

Nitel verilerin analize hazırlanmasında ilk olarak yanıtların tamamı metin halinde verilere dönüştürülmüştür. Araştırmacının verileri yakından tanıması ve veriye hâkim olması çok önemli olduğu için (Kabakçı ve Yurdakul, 2016) verilerin dökümü birebir araştırmacı tarafından yapılmıştır. Verilerin çözümlenmesinde ise içerik analizinden yararlanılmıştır. İçerik analizinde, temelde yapılan işlem, birbirine benzeyen verileri belirli kavramlar ve temalar çerçevesinde bir araya getirmek ve bunu okuyucunun anlayabileceği bir biçimde organize ederek yorumlamaktadır. İçerik analizinde temel amaç, toplanan verileri açıklayabilecek kavramlara ve ilişkilere ulaşmaktır. Bu yolla veriler tanımlanmaya, verilerin içinde saklı olabilecek gerçekler ortaya çıkarılmaya çalışılır (Yıldırım ve Şimşek, 2013). Temalar altında verilen yanıtların sıklık düzeyleri değerlendirilmiştir. Temalar belirlenirken temaların verilen tüm yanıtları kapsamasına dikkat edilmiştir. Yanıtların yalnızca bir tema altında yer almasına ve temaların birbirinden bağımsız olmasına özen gösterilmiştir.

Araştırmayı yürüten araştırmacı, bu işlemleri gerçekleştirirken kendisinden bağımsız olarak bir araştırmacının da aynı işlemi gerçekleştirmesini sağlamıştır. Daha sonra bir araya gelen araştırmacılar, farklı temalar altında değerlendirdikleri görüşler üzerinde tartışarak uzlaşmaya varmışlardır. Bu sayede araştırmanın iç geçerliği sağlanmıştır. Araştırmanın diş geçerliğinin sağlanması için, araştırmanın yöntemi ayrıntılı bir şekilde tanımlanmıştır. Ayrıca araştırmaya birden fazla araştırmacının katılması, araştırma sürecinin açık bir şekilde ortaya konması, ham verilerin saklı olması, araştırma verileri ile araştırmacının mesleki yaşantısında yaptığı gözlemlerle uyuşması ve teyit edilmesi nitel araştırmada güvenirlik ölçütlerini (Yıldırım ve Şimşek, 2005) karşılamaktadır.

\section{Bulgular}

Katılımcıların, görüşme formunda bulunan sorulara verdikleri yanıtlar soru bazında ayrı ayrı incelenmiş, her bir soru için ana temalar ve alt temalar belirlenmiştir. Araştırma sorularına ilişkin bulgular sırası ile aşağıda verilmektedir.

\section{Karar Verme Sürecine İlişkin Bulgular}

1. soruda araştırmaya katılım gösteren koordinatör, yönetici ve öğretmenlere "Çalıştığınız işyerinde karar verme süreci nasıl işlemektedir?" sorusu yöneltilmiş ve katılımcıların bu soruya verdikleri yanıtlar Tablo 2' de, 4 tema altında toplanmıştır. 
Tablo 2. Karar Verme Sürecinde İzlenen Yola Dair Bulgular

\begin{tabular}{|c|c|c|c|}
\hline TEMALAR & $f$ & ALT TEMALAR & $f$ \\
\hline \multirow[t]{2}{*}{ Kişi Odaklı } & 7 & Bireysel & 5 \\
\hline & & Tecrübe & 2 \\
\hline \multirow[t]{2}{*}{ Grup Odaklı } & 6 & Toplant1 & 3 \\
\hline & & Görüş Alışverişi & 3 \\
\hline Kurumsal Çerçeve & 5 & Hiyerarşi & 5 \\
\hline \multirow[t]{3}{*}{ Diğer Unsurlar } & 3 & Bilgievinin Yapısı & 2 \\
\hline & & Siyasi Yapı & 1 \\
\hline & & Mahallenin Yapısı & 1 \\
\hline
\end{tabular}

En fazla sıklığın "Kişi Odaklı" ve "Grup Odaklı" temalarında olduğu görülmektedir. Kişi odaklı alınan kararlar içerisinde 5 defa "Bireysel” kararların alındığı 2 defa ise “Tecrübe"ye dayanan kararların alındığı ifade edilmiştir. "Grup Odaklı" kararlar teması içerisinde ise 3'er defa ifade edilen "Görüş Alışverişi”" ve "Toplantı" yoluyla alınan kararlar öne çıkmaktadır. "Kurumsal Çerçeve" yle ilgili kararlarda ise 5 defa kullanılan "Hiyerarşi" alt temasıyla, ast-üst ilişkisine bağlı kararlar alındığı ifade edilmiştir.

"Kişi Odaklı" kararlar temasına dair örnek ifade aşağıdadır:

"11 senelik bir tecrübem olduğu için karar verirken açık söylemek gerekirse kararlarımı ben kendim alırm." (K3, 42, K)

"Grup Odaklı" kararlar temasına dair bazı ifadeler şunlardır:

“Öncelikle karar alırken ortak kararlarımız var. Bu ortak kararlarımı, yapılan yöneticiler toplantısinda belirleniyor. Ortak karar alındiktan sonra her bir bilgievi, o ortak kararı uyguluyor." (K6, $40, \mathrm{~K})$

"Ĕ̆ger yapılacak işle ilgili karar almak gerekiyorsa zamanım varsa bunu da bilgievinde çalışan personellerle istişare etmeye çalışıyorum." (K4, 39, E)

“Kurumsal Çerçeve" kararlar temasına dair bazı ifadeler şunlardır:

"Şuana kadar alınan kararların daha çok yukarıdan aşağıya-doğru, hiyerarşik bir yapılanma olduğunu çok rahat bir şekilde söyleyebilirim." (K7, 29, E)

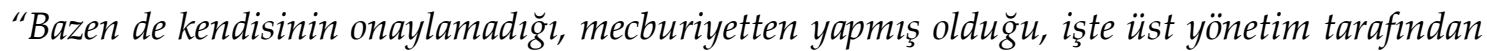
bu şekilde uygun görülüyor, bunu bu şekilde yapmalıyı. Yapacak bir şey yok şeklinde, karar sürecimizi bunlar etkiliyor." (K11, 30, K)

2. soruda katılımcılara "Çalıştığınız bilgievinde karar verme sürecinde etkili olan faktörler nelerdir?" sorusu yöneltilmiştir. Katılımcıların verdiği yanıtlar Tablo 3' de görüldüğü gibi 4 tema altında toplanmıştır. En fazla tekrar eden temaların "siyasi yapı" ve "mahalle ihtiyaçları" olduğu görülmektedir.

Tablo 3. Karar Verme Sürecinde Etkili Olan Faktörlere Dair Bulgular

\begin{tabular}{cccc}
\hline TEMALAR & $f$ & ALT TEMALAR & $f$ \\
\hline Siyasi Yapı & 4 & & 4 \\
\hline Mahalle İhtiyaçları & 4 & & 4 \\
\hline Kişi Odaklı & 3 & Ilkeler & 1 \\
\cline { 2 - 4 } & & İnsan İlişkileri & 1 \\
\hline
\end{tabular}




\begin{tabular}{|c|c|c|c|}
\hline & & İnisiyatif Almak & 1 \\
\hline \multirow[t]{3}{*}{ Kurumsal Çerçeve } & \multirow[t]{3}{*}{4} & Hiyerarşi & 2 \\
\hline & & Hedef ve Amaçlar & 1 \\
\hline & & Yasal Metinler & 1 \\
\hline \multirow{2}{*}{$\begin{array}{l}\text { Diğer } \\
\text { Unsurlar }\end{array}$} & \multirow[t]{2}{*}{11} & Belediyenin İhtiyaçları & 2 \\
\hline & & Bilgievinin Yapısı & 1 \\
\hline
\end{tabular}

"Siyasi yapı" temasında geçen ifade şöyledir:

"Bir defa sonuçta kamuya ait bir kurum olduğu için belli bir çerçeveyle yaklaşmak zorundayız. Üst çerçeve yani bir şemsiye gibi düşünürsek bir defa kamu kurumu olmamız belli bir siyasi partiye mensup olmamız karar alma sürecimizde etkili olur." (K4, 39, E)

"Mahalle ihtiyaçları" temasına bağlı olarak şu ifade örnek olarak gösterilebilir:

"Mahalleye ilk geldiğimde, üç sene önce okulu ziyaret ettim. Okulu ziyarete gittiğimde sohbet esnasında denildi ki bu mahallede Suriyeli mülteci çok fazla. Devlet, Suriyeli mülteciler için demiş ki bu çocuk kaç yaşındaysa, uygun sınıfı neyse o sınıfa yerleştirin demiş. Yerleştirin demiş ama çocuk Türkçe okuma-yazma bilmediği için burada zorluk yaşıyor ve bir kısmı bunu bırakıyor. Daha sonrasında yani biz bunu dert edindik. Çeşitli projeler kapsamında yetişkine yönelik mültecilere Türkçe eğitimi vardı. Bu kapsamda çocuklara bir Türkçe kursu açmak istedik." (K5, 40, E)

\section{Planlama Sürecine İlişkin Bulgular}

3. soruda katılımcılara "Çalıştığınız Bilgievindeki faaliyetler nasıl planlanmaktadır?" sorusu yöneltilmiştir. Katılımcıların verdiği yanıtlar Tablo 4'de görüldüğü gibi 4 tema altında toplanmıştır. 4 ana temanın tamamında verilen yanıtların benzerliği sebebiyle "Karar Verme" sürecinin temalarıyla benzer isimlendirmeler tercih edilmiştir. "Karar Verme" ve "Planlama" süreci tematik açıdan benzerlik gösterse de barındırdıkları bulgular noktasında farklılıklar göstermektedir.

Planlama sürecinin ilk sorusunda en fazla tekrar eden ifadeler "Grup Odaklı" ana temasında olduğu görülmektedir. Temalara bağlı alt temalara ilişkin veriler Tablo 4'te ele alınmıştır.

Tablo 4. Planlama Faaliyetlerinin Yapılışına Dair Bulgular

\begin{tabular}{|c|c|c|c|}
\hline TEMALAR & $f$ & ALT TEMALAR & $\bar{f}$ \\
\hline \multirow[t]{5}{*}{ Grup Odaklı } & 11 & Ortak Ak1l & 4 \\
\hline & & Görev Paylaşımı & 2 \\
\hline & & Toplantılar & 2 \\
\hline & & İstişare & 2 \\
\hline & & Komisyonlar & 1 \\
\hline \multirow[t]{3}{*}{ Kurumsal Çerçeve } & 7 & Merkezi Planlar & 3 \\
\hline & & Akademik Takvim & 2 \\
\hline & & Belirli Günler ve Haftalar & 2 \\
\hline \multirow[t]{3}{*}{ Diğer Unsurlar } & 8 & Bilgievinin Yapısı & 4 \\
\hline & & Tarihler & 3 \\
\hline & & Belediye İhtiyaçları & 1 \\
\hline
\end{tabular}


"Grup Odaklı" ana temasına bağlı "Ortak Akıl” alt temasında kullanılan ifade örneği aşağıda verilmektedir.

"Yaptığımız etkinlikler, programlar, çalışmaları biz fikrimizi sunarak sonuçta yılların tecrübesiyle hangisini yapalım, hangisini yapmayalım; nasıl bir planlama oluşturalım, ortak yine kararla bunu belirliyoruz." (K6, 40, K)

"Kurumsal Çerçeve" teması "Merkezi Planlar" alt temasına verilen örnek ifade aşağıdadır:

“Örnek vereyim mesela bizim yıllık ders planı diyelim, ders planının belli kriterleri var. Bu kriterler bize yukarıdan tebliğ edilir biz onun üzerine kendi iç işleyişimize, bulunduğumuz mahalleye göre bir düzenleme yapıyoruz ama şekil olarak, çerçeve olarak belli bir şablonumuz var." (K4, 39, E)

4. soruda ise katılımclara "Plan dışı gelişen durumlarda nasıl davranırsınız?" sorusu yöneltilmiştir. Katılımcıların verdiği yanıtlar Tablo 5 'te görülmektedir. Bulgulara göre en fazla sıklığın "Kişi Odaklı" ana temasına ait olduğu görülmektedir.

Tablo 5. Plan Dışı Gelişen Durumlara Karşı Sergilenen Yaklaşımlar

\begin{tabular}{cccc}
\hline TEMALAR & $f$ & ALT TEMALAR & $f$ \\
\hline Kişi Odaklı & 12 & İnisiyatif & 5 \\
\cline { 2 - 3 } & & Tecrübe & 3 \\
\cline { 2 - 3 } & & Risk Almak & 1 \\
\cline { 2 - 3 } & & Bireysel Müdahale & 1 \\
\cline { 2 - 3 } & & Tedbirlilik & 1 \\
\cline { 2 - 3 } & 4 & Görev Paylaşımı & 1 \\
\hline Grup Odaklı & & Görüş Alışverişi & 1 \\
\cline { 2 - 3 } & & Üstleplantı & 1 \\
\hline Kurumsal Çerçeve & 1 & Siyaset & 1 \\
\hline Diğer Unsurlar & 2 & Belirsizlik & 1 \\
& & & \\
\cline { 2 - 3 } & & &
\end{tabular}

"Kişi Odaklı" ana temasına "inisiyatif" alt temasında örnek ifade aşağıda verilmektedir:

"İnisiyatif almak mesela ders esnasında bir telefon geliyor. İşte bilmem Çanakkale geçilmez programına bütün öğrencilerin gelmesi lazım. Şimdi ben ders mi yapacağım yoksa şey mi yapacă̆ım, Veli bekliyor dışarıda." (K2, 47, E) Bir diğer ifade: "Ben şahsen inisiyatif almayı benimsiyorum. Aldığım durumlar da olmuştur." (K4, 39, E)

"Kişi Odaklı" ana temasının alt teması olan "tecrübe"ye dair görüşler örneği şöyledir:

"Yani bizim kriz ortamlarımı oluyor. Acil müdahaleler yapıyoruz. Acil müdahale yapabilmek için de bir tecrübeniz olmanız gerekiyor." (K3, 42, K)

"Grup Odaklı" ana temasına ifade örneği şöyledir:

"Biz kendi aramızda hallediyoruz genel akışta. Bu dediğim isimler... Şöyle yapalım, böyle yapalım. O sınıfla o sınıfı birleştirelim." (K10, 27, K)

\section{3. İletişim Sürecine İlişkin Bulgular}

5. soruda katılımcılara iletişim sürecine dair sorular sorulmuştur. Katılımcılara "Bilgievinde hangi tür iletişim araçları kullanılmaktadır?" sorusu yöneltilmiştir. Katılımcıların verdiği yanıtlar 
Tablo 6' da görülmektedir. Bulgulara göre en fazla sıklığın “İnternet Tabanlı Uygulamalar" ana temasına ait olduğu görülmektedir.

Tablo 6. Kullanılan İletişim Araçlarına Dair Bulgular

\begin{tabular}{cccc}
\hline TEMALAR & $f$ & ALT TEMALAR & $f$ \\
\hline İnternet Tabanlı & \multirow{2}{*}{17} & WhatsApp & 9 \\
Uygulamalar & & Mail & 6 \\
& & Sosyal Medya & 2 \\
\hline Karşıllklı İletişim & 8 & Yüz yüze & 8 \\
\hline Grupla İletişim & 4 & Toplantı & 4 \\
\hline Ses Aygitları & 4 & Telefon & 4 \\
\hline
\end{tabular}

"İnternet Tabanlı Uygulamalar" ana temasında en sık tekrar eden alt tema 9 farklı kişinin ifadesiyle, "WhatsApp"tır. 6 defa "Mail", 2 defa ise "Sosyal Medya" olmuştur.

“İnternet Tabanlı Uygulamalar" ana temasına örnek olacak bazı ifadeler şunlardır:

“WhatsApp işte acil durumlarda kullanırım. Genel durumlarda mail kullanırım." (K2, 47, E)

"İletişim araçları olarak genellikle bir iş yapılacaksa bu işte Word, Excel formatında bir işse mail kullanilıyor." (K10, 27, K)

Bir diğer ana tema ise "Karşılıklı İletişim" dir. Bu tema içerisinde sıklıkla ifade edilen görüşler "Yüz Yüze" iletişim alt teması içerisindedir. Örnek olarak:

“...iletişim kurulmakta bazen de yüz yüze iletişim, konuşarak gerçekleşmektedir." (K9, 38, E) "Daha sonra da toplantı, birebir görüşmeler vesaire gibi..." (K7, 29, E)

"Yüz yüze kullanırız ama bu krizlerin devam etmesi sonucunda farklı iletişim kanallarn yani davranış da bir iletişim, tutum da bir tercihtir." (K5, 40, E) ve "Birebir görüşmeler de yapıyoruz toplantılar da yapıyoruz." (K2, 47, E) gibi örnekler siralanabilir.

"Grupla İletişim" temasında ise ifade edilen görüşler "Toplantı" alt teması altında kullanılmıştır.

"Toplantıları neden yapıyorum, toplantılarda genel olan konuları, yapılması gereken işleri ilan etmek şeklinde." (K2, 47, E)

“Tüm personelimizle mümkün olduğu kadar altı ayda bir genel toplantı, pardon, her dönem için; bahar dönemi, güz dönemi ve yaz dönemi için ayrı ayrı toplantılar gerçekleştiriyoruz." (K1, 46, E)

"Ses Aygıtları" alt temasına dair aşağıdaki ifade örnek gösterilebilir:

"A ̆̆ırlıklı olarak cep telefonu kullanmayı tercih ediyoruz. Çünkü arkadaşlar görevi icabı yerinde olmayabiliyorlar." (K1, 46, E)

6. soruda katılımcılara İletişim sürecine dair sorular sorulmuştur. Katılımcılara “Bilgievlerinde iletişim sürecinde karşılaşılan problemler var mı, varsa ne tür problemlerdir?" sorusu yöneltilmiştir. Katılımcıların verdiği yanıtlar Tablo 7'de görülmektedir. Bulgulara göre en fazla sıklığın "Kişilerden Kaynaklı" ana temasına ait olduğu görülmektedir. 
Tablo 7. Karşılaşılan İletişim Problemlerine Dair Bulgular

\begin{tabular}{cccc}
\hline TEMALAR & $f$ & ALT TEMALAR & $f$ \\
\hline \multirow{3}{*}{ Kişilerden Kaynaklı } & \multirow{2}{*}{11} & Yanlış Anlaşılmalar & 5 \\
& & Kişisel Özellikler & 3 \\
& & Dedikodu & 2 \\
& & Unutkanlık & 1 \\
\hline \multirow{2}{*}{ Araçlardan Kaynaklı } & \multirow{2}{*}{3} & İletiye Ulaşamamak & 2 \\
\hline İş Özellikleri & 2 & İletilerin Eksik Gönderilmesi & 1 \\
\hline
\end{tabular}

"Kişilerden Kaynaklı" ana temasının alt teması olan "Yanlış Anlaşılmalar"a dair ifadeler şöyledir:

"Yazılı iletişimde bazen yanlış anlaşılmalar söz konusu olabiliyor veya telefonla iletişim içerisinde çok acil bir durumsa gene aynı şekilde." (K1, 46, E)

"A dediğinizi B diye anlayan kişiler oluyor mesela. İstemiş olduğunuz bir dosya oluyor ondan, hazırlayıp getirmesini istiyorsunuz ama karşınızda tamamen farklı bir şey çıkmış oluyor." (K3, 42, K) "Dedikodu" alt temasına ait bir görüş ise şöyledir:

"Net konuşulmadığı için aramızda yeri geliyor dedikoduya sebep oluyor. Şöyleymiş, böyleymiş yani iletişim problemlerinden dolayı dedikodunun fazla döndü̆̆̈̈nü düşünmekteyim." (K11, 30, K)

"Kişiden Kaynaklı" ana temasına örnek ifadeler şunlardır:

"İşte benim bir tek WhatsApp'ta bir problemim oluyor da görmüyorsam evde görüyorum. Yani geç görebiliyorum birkaç saat sonra görüyorum sürekli açık tutmadığım için." (K8, 28, K)

“Öğretmenlerin de yoğunluğundan kaynaklanan mesela mailini görmemesi, Whatsapp'ı görmemesi.." (K6, 40, K)

\section{4. Örgütleme Sürecine İlişkin Bulgular}

7. soruda katılımcılara "Çalıştığınız bilgievinde, işlerin niteliğine göre uygun kişilerin, uygun işlere verildiğini düşünüyor musunuz? Bu konuda nasıl bir süreç izlenmektedir?" sorusu yöneltilmiştir. Katılımcıların verdiği yantlar Tablo 8'de görülmektedir. Bu soruda verilen yanıtlar “onaylama içeren" ve "örgütlemenin biçimi" yönünden yapılan yorumlar ikiye ayrılmıştır.

Tablo 8. İşlerin Niteliği ve Örgütlemenin Uygunluğuna Dair Bulgular

\begin{tabular}{|c|c|c|c|}
\hline TEMALAR & $f$ & ALT TEMALAR & $f$ \\
\hline \multirow{2}{*}{$\begin{array}{l}\text { Kişilerin Niteliklerine } \\
\text { Uygun İşe Verilmesi }\end{array}$} & \multirow[t]{2}{*}{11} & Uygun İşlere Verilmektedir. & 6 \\
\hline & & Uygun İşlere Verilmemektedir. & 5 \\
\hline \multirow[t]{5}{*}{ Örgütleme Biçimi } & \multirow[t]{5}{*}{12} & Yetenekler & 5 \\
\hline & & Yakınlık İlişkileri & 3 \\
\hline & & Üstlerin Görevlendirmesi & 2 \\
\hline & & Gönüllülük & 1 \\
\hline & & Adillik & 1 \\
\hline
\end{tabular}

“Uygun İşlere Verilmektedir" görüşü etrafında birleşen ifadeler şunlardır:

"Şimdi hem yönetici bazlı hem öğretmen bazlı geneline baktı̆̆ımızda bence yüzde yetmiş beş veriliyor." (K5, 40, E) 
“Evet, uygun işleri, uygun kişilere verildiğini düşünüyorum.” (K10, 27, K) olarak görüşünü ifade etmiştir.

“Uygun İşlere Verilmemektedir" görüşü etrafında ifade veren katılımcıların yorumları şunlardır:

"Hayır... Hayır... Kesinlikle uygun kişiler uygun işlere verilmiş değildir. Çünkü alınan kişileri biz almıyoruz. Biz yönetici olarak görüşmüyoruz. Görüşen kişiler işte belediyede kimler görüşüyorsa $\operatorname{art\imath k..."~(K2,~47,~E)~}$

"Düşünmüyorum işin açıkçası. Çünkü aslında bakarsak sonuçta bir siyasi atmosfer içerisinde olduğumuz için bütün liderler aynı şeyi söylüyor işte seçildiğimizde liyakat, liyakat, liyakat... Ĕ̆ger bütün siyasi liderler aynı şeyi söylüyorsa demek ki bu artık yani küçük ölçekli olmaktan çıkıp ulusal ölçekli bir problem oluşturmuştur." (K7, 29, E)

Soru içerisinde ikinci bir bağlam oluşturan "Bu konuda nasıl bir süreç izlenmektedir?" soru cümlesine dair ortaya çıkan örnek yanıtlar ise şunlardır:

"Evet, ben bu konuda objektif olmaya çalışıyorum. İşi ehline vermeye çalışıyorum." $(\mathrm{K} 4,39, \mathrm{E})$

"En önemli kriter iş verdiğiniz kişinin o işi yapabilecek kabiliyette olması, alanına uygun olması." $(\mathrm{K} 6,40, \mathrm{~K})$

"Bir de burası siyasi bir kurum. Siyasi bir kurum olduğu için yeri geliyor bazen işte hatıragönüle, tanıdık vasıtasıyla olduğu için işin ehli olmayan insanlara iş ya da koltuk veriliyor." (K11, 30, $\mathrm{K})$

Araştırmanın 8. sorusu "örgütleme" basamağının ise 2. sorusu olan "Bilgievinde görev paylaşımındaki ölçüt ya da ölçütler nelerdir?" sorusuna dair belirtilen ifadeler Tablo 9'da ele alınmıştır.

Tablo 9. Görev Paylaşımına Dair Bulgular

\begin{tabular}{|c|c|c|c|}
\hline TEMALAR & $f$ & ALT TEMALAR & $f$ \\
\hline \multirow[t]{4}{*}{ Kişisel Özellikler } & 8 & Yetenekler & 5 \\
\hline & & Gönüllülü̈k & 1 \\
\hline & & Psikolojik Durum & 1 \\
\hline & & Kişisel İliş̧kiler & 1 \\
\hline \multirow[t]{3}{*}{ Mesleki Özellikler } & 5 & Branş & 3 \\
\hline & & Alınan Eğitim & 1 \\
\hline & & Komisyonlar & 1 \\
\hline
\end{tabular}

"Kişisel Özellikler" ana temasına bağlı "yetenekler" alt temasında ifade edilen bazı görüşler şunlardır:

"Mesela bazılarının estetik yeteneği güzeldir. Onlara görüntü işte süsleme işleri. Bazılarının kontrol etme yeteneği yüksektir. Onlara alanı kontrol etme işleri." (K2, 47, E)

“Tekerleme yarışmasını ben İngilizce öğretmenimle yapabiliyorum. Ingilizce öğretmenim bu konuda yetenekli. El yeteneğiyle alakal matematik öğretmenim var. Matematik öğretmeniyle birlikte yapabiliyoruz." (K3, 42, K) 
"Mesleki Özellikler" ana temasının "branş" alt temasında ifade edilen görüş örnekleri şunlardır:

"Bir örnek üzerinden gidersek yani en belirgin örnek nedir bilgievlerinde.. Öğretmenin branşlarına göre atölyelerin paylaştırılması, bu net bir örnektir." (K6, 40, K)

“Tabi ki yani bir rehber öğretmene çıkı da bir bilgisayarla alakalı görev vermiyoruz. Bilgisayar öğretmeniyle alakalı bilişimle alakalı bir görev vermiyoruz haliyle. Rehberlikle alakalı bir görev veriyoruz." (K5, 40, E)

\section{Etkileme Sürecine İlişkin Bulgular}

Araştırmanın 9. Sorusu olan, "Etkileme" sürecine dair bulgu oluşturması hedeflenen soru şudur: "Yöneticileriniz işler yapılırken hangi etki araçlar kullanmakta, çalışanlarım nasıl motive etmektedir?" Bu soruya dair belirtilen görüşler Tablo 10' da yer almaktadır:

Tablo 10. Yöneticilerin Kullandıkları Etki Araçlarına Dair Bulgular

\begin{tabular}{|c|c|c|c|}
\hline TEMALAR & & ALT TEMALAR & ALT TEMALAR \\
\hline \multirow[t]{10}{*}{ Soyut Araçlar } & & Değer Vermek & İşi Takip Etmek \\
\hline & 1 & Ayrıcalık Tanımamak & Destekleyici Olmak \\
\hline & & Güler Yüz & Takdir Etmek \\
\hline & & Adil Davranmak & Rica Dili \\
\hline & & İlkeli Olmak & Üstten Bakmamak \\
\hline & & Konuşarak İkna Etmek & Destekleyici \\
\hline & & Pozitiflik & Tahammül Göstermek \\
\hline & & Samimi İlişkiler & Üst Otorite \\
\hline & & Kontrolcü Olmamak & Azarlama \\
\hline & & Üsluba Dikkat Etmek & Dikte Etmek \\
\hline \multirow{6}{*}{$\begin{array}{l}\text { Somut } \\
\text { Araçlar }\end{array}$} & & İzin Kullandırmak & \\
\hline & & Rahat Ortam Sağlamak & \\
\hline & & Yemek Organizasyonları & \\
\hline & & Gezi Organizasyonları & \\
\hline & & Malzeme Desteği Sağlamak & \\
\hline & & Yasal Metinler & \\
\hline
\end{tabular}

Yöneticilerin kullandıkları etki ve motivasyon araçlarına dair bulgular incelendiğinde, görüşlerin iki tema etrafında toplandığı görülmektedir. "Soyut Araçlar" ve "Somut Araçlar". İki ana tema arasında en fazla ifadenin olduğu tema, 21 defa tekrar eden "Soyut Araçlar" temasıdır. "Somut Araçlar" teması ise 6 defa ifade edilmiştir.

"Soyut Araçlar" ana temasına örnek görüşler şunlardır:

"İ̧̧te birebir görüşmelerde bizimle daha değer vererek bize yaklaşıyor bu da bizi motive ediyor." $(\mathrm{K} 2,47, \mathrm{E})$

"Adil ve ilkesel yani ben adam kayırmam, adil davranırım kimseye işte mesela işte nazma göre şerbet değil hak edene hak ettiği gibi..." (K2, 47, E)

“Genelde rica eder yöneticimiz... Hiçbir zaman emir kipiyle konuşmamıştır." (K8, 28, K)

"Somut Araçlar" ana temasının örnekler şunlardır: 
"İzin yoluyla motive edebiliyor. Yani bizim herhangi bir ekstra durumumuz söz konusu olduğunda bize daha rahat ortamlar sağlıyor." (K2, 47, E)

“Genellikle çok fazla bizi motive ettiklerini söylersem doğru söylemiş olmam. Böyle bir talebimiz olduğu zaman ki genelde o şekilde biz talep ediyoruz, motivasyona ihtiyactmız var diye. Onlar da uygun bir yol bulursa... Bir yemek organizasyonudur bir gezidir..." (K4, 39, E)

\section{Koordinasyon Sürecine İlişkin Bulgular}

10. soru, "Koordinasyon" sürecine yönelik olarak bilgievlerinin özelliklerini ortaya koymayı amaçlamıştır. Katılımcılara sorulan: "Bilgievinde işler arasındaki ve kişiler arasındaki koordinasyon nasıl sağlanmaktadır?" sorusuna verilen yanıtlar, ana ve alt temalara ayrilarak Tablo 11'de gösterilmiştir.

Tablo 11. İşler ve Kişiler Arasında Sağlanan Koordinasyona Dair Bulgular

\begin{tabular}{cccc}
\hline TEMALAR & $f$ & ALT TEMALAR & $f$ \\
\hline Grup Odaklı & 9 & Görev Paylaşımı & 7 \\
\cline { 3 - 4 } & & Görüş Alışverişi & 2 \\
\hline Kişi Odaklı & 6 & Personel Özellikleri & 2 \\
\cline { 3 - 4 } & & Yönetici Odaklı & 4 \\
\hline Kurum Odaklı & 5 & İşlerin Tanımlılı̆̆ & 3 \\
\cline { 2 - 3 } & & Hiyerarşik Yapı & 2 \\
\hline
\end{tabular}

"Grup Odaklı" temasında ifade edilen bazı görüşler şunlardır:

"Bir toplantı şeklinde istişare şeklinde bir değerlendirmemiz oluyor. Burada yönlendirme yapıyoruz. İşler arasında iş paylaşımı yapıyoruz." (K4, 39, E)

“Öğretmenlere iş bölümü yapılmakta, bu şekilde kişiler arasındaki koordinasyonu, organizasyonu görev paylaşımı sırasındaki görev dağılımına göre gerçekleştirilmekte. O işle ilgili kim ise onunla ilgili koordinasyonu sağlanmakta." (K9, 38, E)

"Kişi Odaklı" temasına dair ifade edilen görüşlerden bazıları şunlardır:

"İş tanımına uymamasına rağmen ondan yardım alıyoruz. Burada biraz kişinin becerilerini bilmemizle alakalı bir iş paylaşımı..." (K10, 27, K)

"Belirlenmiş olan asıl sorumlu yönetici nezdinde koordinasyon, görev dağılımı sağlanıyor." (K1, $46, \mathrm{E})$

"Kurum Odaklı" teması bağlamında ifade edilen görüşler şunlardır: $40, \mathrm{~K})$

"Bu planlamaya göre herkes neyi yapacă̆ım biliyor. Neyi, ne zaman yapacă̆ın biliyor." (K6,

"Sonuçta biz üstsek bizim de üstümüz var. Yani bizim de elimizin kolumuzun bağlandı̆̆g yerler oluyor. Dolayısıyla biraz daha hiyerarşik yapı içerisinde rapor etmek zorunda kalıyoruz." (K4, 39, E).

\section{Değerlendirme Sürecine İlişkin Bulgular}

11. soru, "Değerlendirme" sürecine yönelik olarak bilgievlerinin özelliklerini ortaya koymayı amaçlamıştır. "Değerlendirme" sürecine yönelik olarak 2 soru sorulmuştur. 2 soru da değerlendirmeye dair bilgievlerinin çeşitli özelliklerimi betimlemeyi amaçlamaktadır. Katılımclara sorulan: "Bilgievinde kurumsal amaçlara ulaşılıp, ulaşılmadı̆̆g hangi araçlarla 
değerlendirilmektedir?" sorusuna verilen yanitlar, ana ve alt temalara ayrilarak Tablo 12'de gösterilmiştir. Ortaya çıkan bulgular, iki başlıkta yoğunlaşmıştır. Birincisi bilgievlerinin hizmet verdiği noktalardaki tüm çevrenin verdiği dönütlerdir. İkincisi ise bir değerlendirme yöntemi, tekniği veya metodu barındıran araç nitelikli değerlendirmelerdir.

Tablo 12. Kurumsal Amaçlara Uygunluk ve Değerlendirme Araçlarına Dair Bulgular

\begin{tabular}{|c|c|c|c|}
\hline TEMALAR & $f$ & ALT TEMALAR & $f$ \\
\hline \multirow[t]{6}{*}{ Dönütler Eşliğinde } & 17 & Veli Dönütleri & 6 \\
\hline & & Öğrenci Dönütleri & 4 \\
\hline & & Telefon Aramaları & 3 \\
\hline & & Danışmanın Aldığı Dönütler & 2 \\
\hline & & İnternet Sitesi & 1 \\
\hline & & Okul Öğretmen Görüşleri & 1 \\
\hline \multirow[t]{6}{*}{ Araçlar Eşliğinde } & 11 & Raporlar & 3 \\
\hline & & Gözlemler & 3 \\
\hline & & Niceliksel Büyüme & 2 \\
\hline & & Testler & 1 \\
\hline & & Memnuniyet Anketleri & 1 \\
\hline & & Toplant1 & 1 \\
\hline
\end{tabular}

Yanıtlar arasında en az 2 katılımcının verdiği aynı/benzer yanıtlar sıklıklarına göre incelendiğinde en fazla sıklığın "Dönütler Eşliğinde" ana temasına ait olduğu görülmüsstür. $\mathrm{Bu}$ temaya dair görüşler 17 defa tekrar etmiştir. Bu temadan sonra en fazla sıklığ tema "Araçlar Eşliğinde" temasıdır. 11 defa tekrar etmiştir.

"Dönütler Eşliğinde" ana masında ifade edilen bazı görüşler şunlardır:

"Velilerden dönüt alıyoruz. Öğrencilerden dönüt alıyoruz. Telefonlarla aldiğımız dönütleri mutlaka değerlendirip ona göre geri dönüş yapıyoruz." (K5, 40, E)

"Çocuklar anlatıyorlar. Çocuklar buradan çıkarken başlıyorlar, şunu yaptık, bunu yaptık diye..." (K8, 28, K)

"Araçlar Eşliğinde" ana temasına dair ifadeler şunlardır:

"Bununla ilgili olarak zaten bizim her yıl faaliyetlere başlamadan önce yıllık planlarımıza, amaç ve hedeflere göre eğitim programlarımızı hazırlıyoruz. (...) Bunun haricinde de haftalı faaliyet raporu alıyoruz herkesten. Bilgievlerine kaçöğrenci gelmiş kaç atölye yapılmış. Bu şekilde bir takibimiz var." $(\mathrm{K} 1,46, \mathrm{E})$

"Normalde bizim amirlerimiz her zaman sayısal veriler ister, nicelik ister. Nicelik kısmım da biz kendi aramızda yapmış olduğumuz programlarla, okul atölyeleriyle nicelik kısmını çözdük." (K1, 47, E)

12. soru "Değerlendirme" sürecine yönelik olarak bilgievlerinin özelliklerini ortaya koymayı amaçlayan ikinci sorudur. "Değerlendirme" sürecine yönelik olarak 2 soru sorulmuştur. 2 soruda değerlendirmeye dair bilgievlerinin çeşitli özelliklerini betimlemeyi amaçlamaktadır. Katılımcılara sorulan soru şöyledir: "Bilgievinde yöneticiler, eğitim ve personellerle ilgili süreçleri nasıl değerlendirir?" Soruya verilen yanıtlar ana ve alt temalara ayrılarak Tablo 13' de ele alınmıştır. 
Tablo 13. Eğitim ve Personellerle İlgili Süreçlerin Değerlendirmesine Dair Bulgular

\begin{tabular}{|c|c|c|c|}
\hline TEMALAR & $f$ & ALT TEMALAR & $f$ \\
\hline \multirow[t]{7}{*}{ Personel } & 13 & Öğrenci - Veli Memnuniyeti & 5 \\
\hline & & Gözlemler & 2 \\
\hline & & Birebir Görüşmeler & 2 \\
\hline & & Sübjektif Değerlendirmeler & 2 \\
\hline & & Derslere Düzenli Girmek & 1 \\
\hline & & Zümre Toplantısı Performansı & 1 \\
\hline & & Şikâyetler & 1 \\
\hline \multirow[t]{4}{*}{ Eğitim } & 8 & Toplantılar & 3 \\
\hline & & Raporlar & 2 \\
\hline & & Öğretmen Görüşleri & 2 \\
\hline & & Öğrenci Performansı & 1 \\
\hline
\end{tabular}

"Personel" ana temasında ifade edilen bazı görüşler şunlardır:

"Personellerle ilgili ölçme değgerlendirme sürecinde ise personellerin normal derslerine rutin olarak gitmesi, öğrencilerin memnun olması (...) o personelimizden memnuniyetimizi ortaya koyuyor." $(\mathrm{K} 1,46, \mathrm{E})$

"Personellerle ilgili değerlendirmemiz, hani çeşitli kriterlerimiz var. Hem gözlem yaparak değerlendirme yapıyoruz hem de hani verilen işlerin yapılıp, yapılmaması noktasında değerlendirme yapıyoruz." (K11, 30, K)

"Eğitim" temasına bağlı olarak ifade edilen görüşler şunlardır:

“Zaman zaman yapmış olduğumuz zümre toplantılarımız, zümre toplantılarımızda yöneticiler olarak genelde biz de katılmaya çalışıyoruz bu toplantılara. Bu da personellerin aktifliği, aktif olsa bile ayakları tam yere basan bir şekilde vermiş oldukları teklifler veya dönütler mahiyetinde daha ziyade değerlendiriyoruz." (K1, 46, E)

"Yaşadığımız olumsuzlukları rapor halinde sunuyoruz. Bu raporların sonucunda bir dahaki dönem yapılıp yapılmaması gereken, dikkat edilmesi gereken konulara dikkat etmeye çalışıyoruz." (K11, $30, \mathrm{~K})$

\section{Sonuç ve Tartışma}

Bu araştırmanın amacı; 2005 yılından itibaren Türkiye' de yaygınlaşmaya başlayan ve 2008 yılı itibariyle İstanbul ili Küçükçekmece ilçesinde hizmet vermeye başlayan bilgievlerinin yönetim süreçleri bağlamında özelliklerini incelemektir. Bu anlamda farklı yaş özellikleri, cinsiyet özellikleri, iş niteliği ve personellerin kıdemleri gibi çeşitli özellikler göz önünde bulundurularak araştırma yürütülmüştür. Ancak tüm değişkenler arasında en fazla öne çıkan unsurun; araştırmacının plan dâhilinde tutmadığı, yöneticilerin tutum ve davranışlarını belirleyen kişisel özellikler ve merkezi etkiler olduğu görülmüştür. Bu araştırmada; yöneticilerin, yönetim süreçlerine dair belirgin bir sistematik ve düzenden uzak, kendi özellik ve yeterlilikleri çerçevesinde yönetim işlemlerini gerçekleştirdiği bulgusuna ulaşılmıştır.

Bilgievlerinde karar verme sürecinde izlenilen yola dair en baskın özellikler, "Kişi Odaklı" özelliklerdir. Kişi odaklı özelliklerden kasıt; bilgievlerinin, sorumlu yöneticinin kişisel özellik ve yeterliliklerine göre yönetildiğidir. Yöneticinin kişisel özellikler ve yeterliliklerinin, personellerin beklentisi ve algısıyla desteklendiği noktalarda katılımcılar olumlu görüşler 
ifade ederken, yöneticilerin kişisel özellikleri ve yeterlilikleriyle uyum sağlayamayan personellerin bilgievi işleyişine dair daha olumsuz yaklaştı̆̆ 1 görülmektedir. Dolayısıyla karar verme sürecinde yöneticilerin özellikleri, personellerin kararı kabullenmedeki yahut reddetmedeki en büyük paya sahiptir. Taş (2002: 551)'ın yapmış olduğu bir araştırmaya göre: Çalışanların karar verme sürecine, yaratıcı yetenekleriyle katılabilmeleri için bir güven ortamının oluşturulması gerekmektedir. Örgüt içerisinde yaratıcı bir örgüt kültürünün oluşması için ise yüzeysel bir katılım değil, çalışanların görüşlerinin önemsenip değerlendirildiği gerçek bir katılım ortamı sağlanmalı ve çalışanlar bunu hissetmelidir. Kişisel özelliklerin ön plana çıktığı bilgievleri olmakla birlikte, hiyerarşinin çok keskin hissedildiği bilgievleri de mevcuttur. Bu noktada ise hiyerarşinin etkisinin yine yöneticilerin kişisel özellikleriyle ilgili olduğu görülmektedir. Bazı yöneticiler hiyerarşik etkileri kolay kabul ederken, bir kısmı ise direnç göstererek bilgievi menfaatlerine odaklanmaktadır. Yine karar verme sürecinde katılımcılık ve istişareden faydalanılan bilgievlerinin olduğu da görülmüştür. Yöneticiler, bazı kararları kurumsal yetkileri dâhilinde alırken bazı kararlarda ise personellere danıştığı, kısmen de kimi kararları doğrudan personellere bıraktığ görülmüştür. Ancak grupla karar almalarda bir takım yanlılıklar ve diğer grup üyelerinden etkilenmelerinin varolduğu da bilinmektedir. Bazı grup kararlarında bireylerin bağımsız tavır göstermemesi de olasılık dâhilinde tutulmalıdır (Özkalp, 1991: 318).

Karar verme sürecinde etkili olan unsurlar incelendiğinde "Siyaset" kavramının etkili olduğu görülmektedir. Bu etkinin varoluşuna dair önemli bir görüş ortaklı̆̆1 mevcuttur. Belediye başkanının 5 senede bir seçimle belirlenmesi ve bu seçimler doğrultusunda belediye başkanının kendi çalışacağı kişileri belirlemek istemesi, bilgievlerinin işleyişine de etki etmiştir. Bazı katılımcılar tarafından "iş kaygısı" olarak ifade edilen çeşitli kaygılar, kimi noktalarda iş etiğini ve bilgievi öncelliklerini aşmasına sebebiyet vermiştir. Eğitim sürecinin devam ettirilmesiyle belediyenin organize ettiği siyasi parti mitingine katılım arasında kalan bir katılımcı, bilgievi kararlarının öğrencilere eğitim vermek yönünde olduğunu ancak çeşitli sebeplerden dolayı tüm personellerle birlikte siyasi mitinge gitmek durumunda kalındığını ifade etmiştir. Gökçe, Şahin ve Örselli (2002)'nin yapmış olduğu araştırmada: Siyasi iktidarlar, yöneticilerin seçiminde ve atanmasında liyakat ve tecrübe gibi ölçütler yerine; güvenilirlik, sır tutmak ve parti menfaatlerini her şeyin önünde tutmak gibi özellikler aradığ 1 belirtilmiştir. Bürokratik ve siyasal bir sistem olan belediyelerde ise karar verme süreci başta olmak üzere birçok sürecin siyasetten etkilenmesi olasılık dâhilindedir. Siyasi dayatmaların ve baskıların olduğu bir iş ortamında ise; verilen kararların, kullanılan iletişim dilinin, yapılacak değerlendirmelerin ve sonuç olarak yönetim süreçlerinin de buna bağlı olarak etkileneceği tahmin edilmektedir. Bundan hareketle kurumlarda örgüt içerisinde çatışmalar oluşabilmektedir. Güç koalisyonlarının oluşması, bireylerin, grupların birbirleri üzerinde etki oluşturma çabası içerisine girmesi gibi somut gerçeklikler mevcuttur. Bu sebeple politik davranışlar; yönetici, öğretmen ve diğer paydaşlar tarafından sergilenebilmektedir. Bu durum, insanın stratejik ve kendi çıkarları doğrultusunda davranma eğiliminin doğal bir örneğidir (Altun ve Sarpkaya, 2017: 10). Karar verme sürecinde mahalle ihtiyaçları oldukça önemlidir. Bilgievlerinin bulunduğu mahallelerin sosyolojik ve eğitsel özelliklerinin karar verme sürecinde etkili olduğu görülmektedir. Verilen bazı kararlarda mahallenin ihtiyaçları göz önünde bulundurulmaktadır. Örnek olarak Suriyeli nüfusunun fazla olduğu bir bölgede, Suriyeliler için okuma-yazma kursu açılmasıdır. Bu ve bunun gibi hizmetler, mahalleli ve kurum arasında bir bağ oluşturmaktadır. Bu sebeple mahalle ihtiyaçlarına yönelik geliştirilen 
etkinliklerin dış verimlilikleri yüksek olmalıdır çünkü halk eğitimi etkinliklerinin sonuçları toplumda çabuk gözlemlenmektedir. (Tekin, 1991: 16)

Yöneticilerin bilgievi amaçlarına yönelik planlamalar yapabilmesinin önünde çeşitli engeller mevcuttur. Bu engellerden bir tanesi de finansmandır. Yöneticiler eksiksiz bir plan yapabilir ancak bu planların uygulanabilmesi ve hedeflerin gerçekleştirilebilmesi için bu planların finanse edilmesi gerekmektedir. Farklı bir ifadeyle plan ile bütçe arasında ilişkinin kurulabilmesi gerekmektedir. Aksi takdirde hedeflerin gerçekleşmesi yolunda merkezi bütçe ve finansmanlar, alt birimlerin planlamalarını aksatabilmektedir (Özdoğan Özbal, 2018: 48). Araştırmada görüş ifade eden yöneticiler, en düşüğü 4 sene en yükseği 11 sene yöneticilik tecrübesi olan, kısmen de öğretmenlik tecrübesi olan yöneticilerdir. Dolayısıyla planlama sürecinde tecrübelerinden de faydalanmaktadırlar. Tecrübenin yanında bir diğer etkili olan unsur ise inisiyatif almaktır. Katılımcıların 5'i, yöneticilerin inisiyatif alarak kriz yönetimi yaptığını, plan dışı durumlara müdahale ettiğini ifade etmektedir. İnisiyatif almak, sistemli ve bütüncül müdahalelere nazaran daha öngörülemez sonuçlar doğurabilirler. "Metodolojik bir yaklaşımın bulunmadığı organizasyonlarda olağanüstü durumlara verilen tepkiler bireysel aksiyonlarla şekillenmekte, aksaklikların giderilmesinde bireylerin inançlarn ve şans faktörü önemli bir rol üstlenmektedir" (Karaağaç, 2013: 131). Plan dışı durumlara müdahale durumlarında kişisel özelliklerin dışında grup özelliklerinin de yer yer kullanıldığı görülmektedir. Plan dışı bir durum geliştiğinde görev paylaşımı yapılarak, duruma müdahale edilen bilgievleri de mevcuttur.

Bilgievlerinde sıklıkla kullanılan iletişim araçları, "İnternet Tabanlı Uygulamalar", ve "Karşılıklı İletişim"dir. İki iletişim türü de bilgievlerinde yaygın olarak kullanılmaktadır. İnternet tabanlı uygulamalar içerisinde kullanılan araçlar şunlardır: WhatsApp, mail, sosyal medya ağları ve diğer elektronik imkânlar. Katılımcıların büyük çoğunluğu iş ortamında WhatsApp'la haberleşildiğini ifade etmektedir. Bu bulgunun arkasında yatan sebepler en bariz şekliyle, 10 adet şubeyle hizmet veren bilgievlerinin kendi aralarında duydukları iletişim ihtiyacıdır. Bir diğer sebebi ise öğretmenlerin üyesi oldukları zümredeki öğretmenlerle iletişim kurma ihtiyacıdır. Aynı çalışma ortamını paylaşmayan, farklı bilgievi yönetici ve öğretmenler, çoğunlukla WhatsApp gruplarıyla iletişimlerini sağlamaktadır. WhatsApp uygulamasının tercih edilme sebepleri arasında pratikliğin yanında; belge, broşür, video, görsel tanıtım-medya unsurlarının tüm personeller arasında paylaşımı da gösterilebilir. Uzun ve Uluçay (2017: 228)'ın yaptığı araştırmada içerisinde medya zenginliği barındıran araçların, iletişimin etkinliğini artırdı̆̆ ifade edilmiştir.

İletişim sürecinin ikinci bağlamını ise iletişimde karşılaşılan problemler oluşturmaktadır. İletişim problemlerin yaygın olarak görüldüğü durumlar genellikle "Kişilerden Kaynaklı" durumlardır. $\mathrm{Bu}$ problem içerisinde en yaygın olarak görülen problem ise "Yanlış Anlaşılmalar"dır. Katılımcıların önemli bir kısmı, bilgievlerindeki çalışma ortamlarında yanlış anlaşılmaların sıklıkla geliştiğini ifade etmekteler ve bunu bir iletişim problemi olarak görmektedirler. Yanlış anlaşılmaların önemli bir sebebi ise iletişim imkânlarından doğru bir şekilde faydalanılamamasıdır. Bu noktada yanlış anlaşılmaların iletişimi, iletişimin ise yanlış anlaşılmaları etkilediği ve tetiklediği değerlendirmesi yapılabilir. Mesleki bilgi ve beceriyi artırdığ 1 düşünülen hizmet içi eğitimlerin, personellerin iletişim problemleriyle baş etmesine de fayda sağlayacağı düşünülmektedir. Şen, Yılmaz ve Ünüvar (2013: 19)'ın hemşirelerle yapmış olduğu bir araştırmaya göre hizmet içi eğitimler, personellerin yüksek iletişim 
becerileri kazanması ve yaşanan çatışma, gerginlik ve olumsuzlukların çözülmesi noktasında önemlidir.

Kişilerden kaynaklı iletişim problemlerinde ifade edilen bir diğer unsur ise "Kişisel Özellikler"dir. Kişisel özellikler, personeller arasındaki iletişime etki etmektedir. Katılımcıların ifadesine göre personellerin psikolojik özellikleri iletişim adına kimi problemler ortaya koymaktadır. Bu problemlerin bir diğer sebebi iletişim dilinin yoruma açık yönler barındırması ve sınırlı bir netliğe sahip olmasıdır. Bu aynı zamanda ifade edildiği üzere dedikodu gibi iletişim problemlerinin ortaya çıkmasına da sebebiyet vermektedir. Bilgievi personellerinin arasındaki dedikoduların ortaya çıkış sebepleri irdelenirken göz önünde bulundurulması gereken kimi noktalar vardır. Arabacı, Sünkür ve Şimşek (2012: 187)'in yaptığı araştırmaya göre dedikodu eyleminin arkasında yatan sebepler arasında kıskançlık ve çekememezlik gibi unsurlar yer almaktadır. Ortak ve paylaşılmış bir vizyonun olmadığı kurumlarda bireysel çıkarların ön plana çıkması olasılık dâhilindedir. Uzun, Ayık ve Özdem (2019: 35)'in yaptığı araştırmada: Eğitim kurumlarında örgütsel iletişimin düzeyi arttıkça öğretmenlerin iş motivasyonunun arttığ1 ifade edilmiştir. Eğitim kurumundaki örgütsel iletişimi düzeyi, iş doyumunu açıklamada da önemli bir değişken olduğu görülmektedir.

İletişim sürecinden sonra ele alınan bir diğer süreç "Örgütleme" sürecidir. Personellerin uygun işlere verilip/verilmediği hususundaki düşünceler sübjektif/objektif yönler barındırsa da bilgievleri özelinde, belediyelerdeki birimlere personel alımı yaparken; ilgili birimin müdürü, belediye başkan ve başkan yardımcılarının iradesinin önemli bir etkisinin olduğu görülmüştür. İşe alım noktasında yasal mevzuat ve yönetmeliklere dair belge ve ifadelere rastlanmamıştır. Bu bağlamda katılımcıların genel görüşleri ele alındığında personel seçimi noktasında yeteneklerin önemli bir etken olduğu görülmektedir. Branşların niteliklerine uygun örgütlemelerin yer aldığı görülmektedir. Yetenekten sonra örgütlemedeki en büyük araç yakınlık ilişkileri ve üstlerin görevlendirmesiyle ilgili unsurlardır.

"Örgütleme" sürecinden sonra ele alınan yönetim süreci "Etkileme"dir. Etkileme süreci iki bağlamda ele alınmıştır: "Soyut Araçlar" ve "Somut Araçlar". Bu ayrımın yapılmasının sebebi, her bir katılımcının karakter özellikleriyle de açıklanabilecek araçların olduğudur. Soyut araçlar genellikle kişilerin manevi yönden hazzını, motivasyonunu sağlayan araçlarken somut araçlar ise iş özellikleriyle ilgili; maddi, menfi kazanımların elde edildiği araçlardır. Etkileme sürecinde "kişisel özellikler" den kaynaklı kimi araçlar kullanılmıştır. Haveydi ve Alpaydın (2019: 139)'ın yaptı̆̆ı bir araştırmaya göre: Öğretmenlerin algılarına göre eğitim yöneticilerinin öğretmenleri etkileme ölçeğinde en yüksek etkileme tarzının "kişilikle etkileme" daha sonra "uzmanlıkla etkileme" ve en az ise "yetkiyle etkileme" olduğu görülmüştür. Haveydi ve Alpaydın (2019)'ın araştırmasında "kişilikle etkileme" maddesini destekler nitelikte verilere ulaşılmıştır. Günbayı, Dağlı ve Kalkan (2013: 593)'ın yaptığ1 çalışmada, eğitim yöneticilerinin; duygusal, öğretimsel ve araçsal desteği ile öğretmenlerin örgütsel vatandaşlık davranışlarının arasında olumlu bir ilişki olduğu ortaya çıkmıştır. Öğretmenlerin, yönetim tarafından desteklendiklerini algıladıklarında işe olan bağlılıklarının arttığı ve görev alma noktasında daha olumlu yaklaşımlar gösterdiği ifade edilmiştir. Değer vermek, güler yüzlü olmak, destekleyici bir tavır sergilemek gibi araçların kullanıldığ bilgievlerindeki katılımcıların görüşleri ele alındığında araştırma sorularına tepkisel yaklaşılmadığı, süreçlere dair daha pozitif yorumlar yapıldığı gözlemlenmiştir. Bir örgütte, yönetim stili, iletişim sistemi, personele verilen değer, başarıyı takdir etme, sorun çözme becerileri, değişim ve yeniliğe karşı tutumlar ne kadar olumlu ve güçlü olursa örgüt kültürü 
de buna bağlı olarak olumlu ve güçlü olacaktır (Avcı, A., 2016: 5384). Etkileme sürecinde yöneticilerin kullandığı somutluk barındıran araçlar ise şunlardır: İzin kullandırmak, rahat bir çalışma ortamı sağlamak, yemek ve gezi organizasyonu düzenlemek, malzeme desteği sağlamak ve yasal metinlerin etkisini kullanmak gibi çeşitli araçlar mevcuttur. Şirin (2009: 37)' in yapmış olduğu araştırmaya göre ödül, ücret gibi somut araçların iş doyumunu artırdığ bulgusuna ulaşılmıştır. Dolayısıyla somut etkileme araçları, çalışanlar arasında pozitif bir etki uyandıracağı sonucuna ulaşılabilir.

Yönetim süreçlerinin sonuncusu olan "Değerlendirme" basamağına bağlı bulgular incelendiğinde değerlendirme sürecinin iki araçla gerçekleştiği gözlemlenmektedir. Birincisi "Araçlar", ikincisi ise "Dönütler"dir. Araçlardan kasıt belirli bir temeli olan, kısmen bilimsellik barındıran ve sistematik bir şekilde uygulanan ölçme ve değerlendirme unsurlarıdır. Dönütlerden kasıt ise bilgievlerinden hizmet alan çevreden gelen sözlü yahut yazılı bildirimlerdir. Yöneticinin eğitim sürecinin takipçisi olduğu ve çeşitli gözlemlerle kurumsal amaçlara ulaşılıp/ulaşılmadığını değerlendirdiği görülmektedir. Dönütler, çoğunlukla bilgievinin hizmet verdiği çevreden; internet siteleri, telefon aramaları ve bilgievi danışmanı aracılığıyla gönderilen bildirimlerdir. Dönütlerin en çok alındığı kişiler ise velilerdir. Ancak öğretmenlerin, öğrenciler üzerinde yaptığı bütüncül nitelik taşımayan gözlemler ve öğrencilerin sınırlı bir algılayışla verdiği dönütler bilgievlerinin kurumsal amaçlarına ulaşabilme noktasında önemli bir ciddiyet sağlamamaktadır. Personellerin değerlendirilmesinde bilimsel, araçsal uygulamaların son derece sinırlı olduğu görülmektedir. Genellikle personel değerlendirmeleri: Gözlemler, birebir görüşmeler, sübjektif değerlendirmeler, derslere düzenli girmek, zümre toplantılarındaki performans ve alınan şikâyetlerle yapılmaktadır. Bu noktada bazı katılımcıların da ifade ettiği gibi bilgievlerinde personel değerlendirme işlevini yerine getirecek sistemsel bir alt yapı kurulamadığı düşünülmektedir. Performans değerlendirme araçları, kurumlar ve çalışanlar için oldukça önemlidir. Topuz ve Yılmaz (2019: 103)'ın yaptığı araştırmaya gore: Öğretmenlerin bir değerlendirmeye tâbi tutulacaklarını bilmeleri, yapılacak olan değerlendirmenin de belli ölçütlere göre yapılması, öğretmenlerin sürekli bir hazırlık içerisinde olmasını gerektirmektedir. Çünkü öğretmenler sürekli olarak kendilerini geliştirmek zorunda hissetmektedirler.

\section{Öneriler}

\section{Uygulayıcılara Öneriler}

$\mathrm{Bu}$ araştırmada ortaya çıkan bulgular ve sonuçlar ele alındığında; yerel eğitim unsurlarının tamamı ve kısmen de Milli Eğitim Bakanlığına bağlı olarak hizmet veren özel okullar ve devlet okulları yöneticilerinin dikkat etmesi gereken bir takım öneriler mevcuttur.

- Karar verme sürecinde çoğulcu bir yöntem izlenilmesi durumunda personeller olumlu tutumlar içerisine girmesini sağlayacaktır.

- Planlama sürecine personellerin de dâhil olması kurumun etkililiğini arttıracaktır.

- Personellerle yüz yüze iletişimler gerçekleştirilmesi tavsiye edilmektedir.

- Kurum içerisindeki iletişimin kayıtlı yazışmalarla yürütülmesi tavsiye edilmektedir.

- Örgütleme sürecinde "liyakat" çerçevesinde hareket edilmesi tavsiye edilmektedir. 


\section{Araştırmacılara Öneriler}

Bilgievleriyle ilgili çalışmaların alanyazındaki sınırlılı̆̆ henüz çok yeni olduğunu göstermektedir. Bu sebeple bilgievleriyle ilgili yapılacak araştırmalar "tanımlayıcılık" noktasında oldukça önemlidir.

Bilgievleri bağlamında öneriler:

- Bilgievleri bir eğitim modeli olarak irdelenebilir; program hazırlama aşamaları, eğitim süreci ve ölçme-değerlendirme süreci gibi başlıklarda çalışmalar yürütülebilir.

- Bilgievlerinin, Milli Eğitim Bakanlığıyla işbirliğinin boyutlarına veya entegrasyonuna dair çalışmalar yürütülebilir.

- “Yerel Eğitim" kavramına uygulama yönüyle bir boyut kazandırmak amacıyla var olan diğer yerel eğitim modelleri incelenebilir.

- Belediyelerin eğitime katkıları, sorumlulukları daha geniş bir çerçevede ele alınabilir.

- Bilgievleri de dâhil olmak üzere belediyelerde personel istihdamı ve özlük hakları konularında araştırma yapılabilir.

\section{Katkı Oranı Beyanı}

Araştırmacılar çalışmaya eşit düzeyde katkı sağlamıştır.

\section{KAYNAKÇA}

Altun, B. Ve Sarpkaya, R. (2017). Eğitim Yönetiminde Politik Modeller. Adnan Menderes Üniversitesi Eğitim Fakültesi Eğitim Bilimleri Dergisi, 8(2): 10.

Arabacı, İ., Sünkür, M.., Şimşek, F. (2012). Öğretmenlerin Dedikodu ve Söylenti Mekanizmasına İlişkin Görüşleri: Nitel Bir Çalışma. Kuram ve Uygulamada Ĕ̆itim Yönetimi Dergisi, 2(2): 187-188

Avcı, A. (2016). Örgüt Kültürünün Örgütsel Vatandaşlık Davranışlarına Etkisi, Journal of Human Sciences, 13(3): 5384.

Büyüköztürk Ş., Kılıç Çakmak, E., Akgün, Ö. E., Karadeniz, Ş., Demirel, F. (2012). Bilimsel Araştırma Yöntemleri, (13. Bask1). Ankara: Pegem A. 20.

Creswell, J.W. (2013). Nitel araştırma yöntemleri (M. Bütün ve S. B. Demir, Çev.). Ankara: Siyasal Kitapevi.

Cömert, I. ve Kayıran, S.M. (2010). Çocuk ve Ergenlerde İnternet Kullanımı. Çocuk Dergisi, 10(4): 167.

Demircan, C. (2007). Köy Enstitüleri Eğitim-Öğretim Programlarında Çocuk Edebiyatı. D.Ü. Ziya Gökalp Eğitim Fakültesi Dergisi, 0(8): 21

Doğan, R. (1997). Osmanlı Eğitim Kurumları ve Eğitimde İlk Yenileşme Hareketlerinin Batılılaşma Açısından Tahlili. Ankara Üniversitesi İlahiyat Fakültesi Dergisi, 37(1): 415

Ersoy, A., F. (2016). Fenomenoloji, Eğitimde nitel araştırma desenleri (A. Saban, A. Ersoy, Ed.) içinde (s. 51-105). Ankara: Anı Yayıncılık.

Gökçe, G., Şahin, A., Örselli, E. (2002). Türkiye'de Siyasetin Bürokrasi Üzerindeki Etkisi: Siyasallaşma. SÜ İ̈BF Sosyal ve Ekonomik Araştırmalar Dergisi, 0(4): 56. 
Günbayı, İ, Dağlı, E, Kalkan, F. (2013). İlköğretim Okulu Müdürlerinin Destekleyici Davranışları ile Öğretmenlerin Örgütsel Vatandaşlık Davranışları Arasındaki İlişki. Kuram ve Uygulamada Ĕ̆itim Yönetimi Dergisi, 4(4): 593.

Haveydi, C. ve Alpaydın, Y. (2019). Okulöncesi Eğitim Kurumu Müdürlerinin Yönetim Becerileri ile Etkileme Güçleri Arasındaki İlişkilerin Öğretmen Görüşlerine Göre İncelenmesi. İstanbul Gelişim Üniversitesi Sosyal Bilimler Dergisi, 6 (1): 139.

Kabakçı Yurdakul, I. (2016). Nitel veri analizinin temelleri. Işıl Kabakçı Yurdakul Editör, Nitel veri analizinde adım adım NVivo kullanımı (s.1-21). Ankara: Anı Yayıncılık.

Karaağaç, T. (2013). Kriz Yönetimi ve İletişim. İ.Ü. Siyasal Bilgiler Fakültesi Dergisi, 0(49): 131.

Karadeniz, Ş. (2017). Yeni Bir Bilgi ve Öğrenme Merkezi Olarak Bilgi Evleri. Türk Kütüphaneciliği, 31(1), 90-104.

Kavi, E., Koçak, O. (2010). İstanbul'daki Bilgi Evlerinin Sosyal İçerme Boyutu Açısından Değerlendirilmesi: Uluslararası 8. Bilgi, Ekonomi ve Yönetim Kongresi Bildirileri. 8. Uluslararası Bilgi, Ekonomi ve Yönetim Kongresi. İstanbul Üniversitesi, İstanbul.

Kırık, Ö. (2007). İnternet Kafeler ve Ortaya Çıkan Sorunlar: İlköğretim Öğrencileri, Öğretmenleri ve Internet Kafe İşletmecileri Üzerine Bir Araştırma, (Yayınlanmamış Yüksek Lisans Tezi). Adnan Menderes Üniversitesi, Aydın.

Kuzu, A. (2011). İnternet ve Aile. Aile ve Toplum Dergisi, 7(27): 10.

Miles, M. B., \& Huberman, A. M. (2015). Nitel veri analizi (S. Akbababa Altun ve A. Ersoy, Çev.). Ankara: Pegem Akademi

Özdoğan Özbal, E. (2018). Yükseköğretim Yöneticilerinin Bireysel Planlama Davranışlarının Örgütsel Planlama Davranışlarına Etkisi Konusundaki Görüşleri. Buca Eğitim Fakültesi Dergisi, 0(45): 48.

Özkalp, E. (1991). Örgütlerde Grupların Karar Verme Teknikleri. Eskişehir Anadolu Üniversitesi İktisadi ve İdari Bilimler Fak. Dergisi, 9(1-2): 318.

Şen, H. T., Yılmaz, F. T., ve Ünüvar, Ö. P. (2013). Hizmet İçi Eğitim Hemşirelerinin İletişim Beceri Düzeyleri. Psikiyatri Hemşireliği Dergisi, 4(1): 19.

Şirin, E. F. (2009). Beden Eğitimi ve Spor Yüksekokullarında Görevli Araştırma Görevlilerinin Mesleki Doyum Düzeylerinin İncelenmesi. CBÜ Beden Eğitimi ve Spor Bilimleri Dergisi, 4(1): 37.

Tabancalı, E. ve Cengiz, F. (2018). Okul Müdürlerinin Öğretim Liderliği Davranışlarının Öğretmenlerin İş Doyumuna Etkisi. Mersin Üniversitesi Ĕ̆itim Fakültesi Dergisi, 14(2): 494.

Taş, H. (2002). Yaratıcı Örgüt Kültürünün Oluşturulmasında Yönetim Süreçlerinin Yönetimi. Kuram ve Uygulamada Ĕ̆itim Yönetimi Dergisi, 32(32): 551.

Tekin, M. (1991). Halk Eğitimi Örgütlerinin Özellikleri ve Halk Eğitimi Örgütüne Açık Sistem Yaklaşımı. Ankara Üniversitesi Ĕ̆itim Bilimleri Fakültesi Dergisi, 24(1): 16.

Topuz, M. ve Yılmaz, K. (2019). Okul Müdürleri ve Öğretmenlerin Performans Değerlendirme Süreci Hakkındaki Görüşleri: Nitel Bir Araştırma. Eğitim Bilimleri Araştırmaları Dergisi, 9(2): 103. 
Türk Dil Kurumu. (2011). Türkçe Sözlük, (11. Baskı). Ankara: Türk Dil Kurumu Yayınları.

Uzun, K., Uluçay, D. (2017). İş Ortamında Whatsapp Kullanımı ve Kesintiye Uğrama. Selçuk Üniversitesi İletişim Fakültesi Akademik Dergisi, 10(1): 229.

Uzun, T., Ayık, A., Özdem, G. (2019). İlkokullarda Örgütsel İletişim ile Öğretmenlerin İş Motivasyonu Arasındaki İlişkiler. Ulusal Ĕ̆itim Akademisi Dergisi, 1(3): 35.

Yavuz, İ. (2013). Sosyal Belediyecilik Bağlamında Çocuk ve Gençlik Hizmetleri: Adapazarı Belediyesi Bilgi Evi Örneği (Yayınlanmamış Yüksek Lisans Tezi). Yalova Üniversitesi, Yalova.

Yıldırım, A., Şimşek, H. (2013) Sosyal Bilimlerde Nitel Araştırma Yöntemleri, (9. Baskı). Ankara: Seçkin Yayıncılık.

Yılmaz, B. (2013). Türkiye'de Köycülük ve Köy Enstitüleri, (Yayınlanmamış Yüksek Lisans Tezi). Karadeniz Teknik Üniversitesi: Trabzon. 